Int. J. Dev. Biol. 64: 109-121 (2020)

https://doi.org/10.1387/ijdb.190189ps

\title{
Research on early mammalian development in India
}

\author{
POLANI B. SESHAGIRI* and VENKATAPPA VANI \\ Department of Molecular Reproduction, Development and Genetics, Indian Institute of Science, Bangalore, India
}

\begin{abstract}
Historically, research in India on early mammalian development had only begun, rather modestly, in the last century, unlike the USA and UK. In India, initial studies were on gonadal and reproductive tissue development and function and they were limited to anatomical and histological characterization. This was followed by research on fertility regulation and contraception. Since the 1960s, a major initiative took place regarding endocrine biochemistry and the use of antifertility agents in inhibiting gonadal function and early development. Post-independence, the Indian government's funding support enabled universities and institutions to embark on various research disciplines in biology but with no particular emphasis on developmental biology per se. Subsequently, India made significant progress in the area of mammalian reproduction and development, but not specifically in the core aspects of developmental biology. Reasons for this could be due to the nation's compulsion to invest and embark on socio-economic and infrastructure development and on research involving family planning methods for reversible-affordable contraceptives to curtail population growth. With regard to the latter, biologists were involved in hormone-based contraception research. During this pursuit, insights were achieved into basic aspects of the development of gonads, gametes and embryos. Notwithstanding this, in the post-1980s through to the present time, Indian scientists have contributed to (i) the understanding of the cellular and molecular regulation of early development, (ii) developing genetically modified mouse models, (iii) using assisted reproductive technologies, generating mammalian progeny, including humans and (iv) deriving pluripotent stem cell lines for developmental studies. This article provides a perspective on the past and current status of early mammalian development research in India.
\end{abstract}

KEY WORDS: gametogenesis, embryogenesis, implantation, early pregnancy

\section{Introduction}

The history of mammalian developmental biology and embryology research reveals very interesting facts in the context of both the global and the Indian scenario. In this article, we provide an initial description of the global perspective, followed by the status of Indian research on early mammalian development and a discussion on India-specific issues on mammalian reproduction and development research. We avoided information on the non- mammalian development model organisms since they are covered in other chapters of this journal issue.

Historically, it is acclaimed that the origin of embryology is traditionally associated with Aristotle who was the first to define a basic problem that dominated embryology (Needham, 1959). In the early 1300 s, Mondino was one of the earliest anatomists who performed dissection of human embryos and contributed to the beginning of embryo-uterine biology research (Mondino, 1478). Similarly, in the late 1400s, the contribution of Leonardo da Vinci was significant pertaining to quantitative observations on human embryonic development (Needham, 1959). This is followed by William Harvey who brought in the dynamic conception of embryology (De Felici and Siracusa, 2000) and research continued through the $17^{\text {th }}$ century (Needham, 1959). During this era, mammalian embryology remained a purely descriptive discipline and experimental embryology had only begun with studies on fertilization and early development in mammalian models, such as rabbits and bats (Van Beneden and Julin, 1880). However, the turning point of modern mammalian embryology was only when Malpighi and Spallanzani began making microscopic observations of embryos being experimented (Needham, 1959).

In the early-mid part of the $20^{\text {th }}$ century, a great revolution occurred in experimental embryology research in the USA, UK and

Abbreviations used in this paper: ART, assisted reproductive technology; EGFP, enhanced green fluorescent protein; ICM, inner cell mass; IVF-ET, in vitro fertilization+embryo transfer; TE, trophectoderm. *Address correspondence to: Polani B. Seshagiri, Dept. of Molecular Reproduction, Development and Genetics, Indian Institute of Science, Sir CV Raman Road,
Bangalore 560012, India. Tel: 080-22932687. Fax: 080-23600999. E-mail: polani@ @iisc.ac.in - (iD) https://orcid.org/0000-0002-5565-9473

Submitted: 11 July, 2019; Accepted: 19 August, 2019.

ISSN: Online 1696-3547, Print 0214-6282 


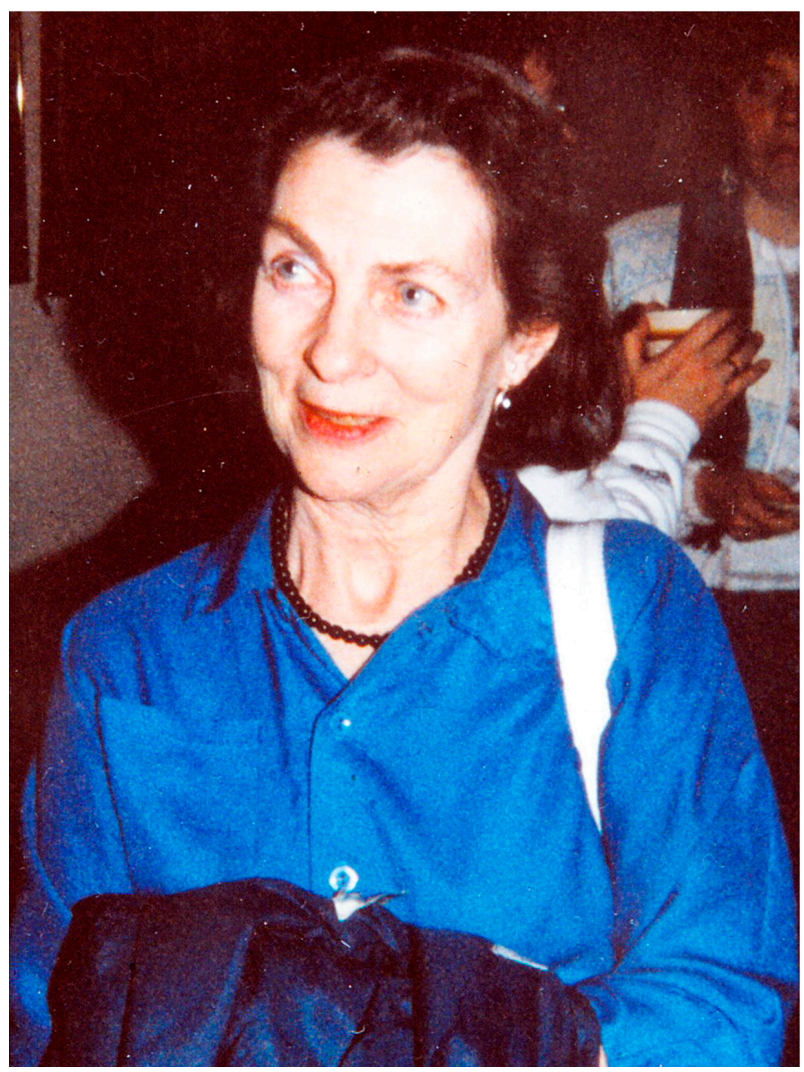

Fig. 1. Prof. Anne McLaren, a frequent visitor to India (IISC), under the Indo-UK visiting programme. The picture was taken in February 1990. elsewhere. During this period, many discoveries were made which include (i) gamete function and fertilization (Needham, 1959; Mulnard, 1986), early embryonic cell lineage commitment (Gardner and Papaionnou, 1975) and earliest development of primordial germ cells (PGCs) in the mouse (McLaren, 1992); (ii) generation of mouse chimeras (Gardner, 1968; McLaren, 1976) and their application in genetics, immunology and other allied areas (Mintz, 1974); (iii) genetic modification of the mouse genome viatransgenic (Constantini and Lacy, 1981; Palmiter et al., 1982; Papaioannou, 1998) and knock-out approaches (Thomas and Capecchi, 1987); (iv) establishment of pluripotent stem cell (PSC) lines (Evans and Kaufman, 1981), in vitro development of early post-implantation embryos and (v) embryo cloning technologies (Wilmut et al., 1997). While these achievements were made by many developmental biologists, of particular mention in this context is the outstanding contributions made by Anne McLaren for over half a century (Fig. 1). Dr. McLaren was a pioneer in mouse embryology and she made a few visits to India (IISc; under the Indo-UK exchange visitors program) and infused, in part, the early development research initiative in India. In this article, we provide a brief historical and contemporary perspective on early mammalian development and reproduction research in India.

\section{Status of Research on Reproduction and Developmental Biology in India}

\section{Early phase}

In India, the emergence of early mammalian development research, as a discipline, occurred alongside the general progress of the natural science in a few academic departments in univer-

TABLE 1

\section{INDIAN UNIVERSITIES/INSTITUTIONS INVOLVED IN RESEARCH ON MAMMALIAN REPRODUCTION AND DEVELOPMENT (HISTORICAL PERIOD\#)}

\begin{tabular}{|c|c|c|c|}
\hline SL No. & University/Institute (Year of establishment) & Departments involved in MRDR & Area of Research \\
\hline 1 & Madras Christian College, Chennai (1837) & Zoology (1885) & Endocrinology \\
\hline 2 & University of Calcutta, Calcutta (1857) & Zoology (1919) & Reprod. endocrinol. \\
\hline 3 & University of Mumbai, Mumbai (1857) & Life sci. (>1857) & Histopathology, Reproduction \\
\hline 4 & University of Madras, Chennai (1857) & Zoology (1927) & Herbal contraceptive biology \\
\hline 5 & University of Lucknow, Lucknow (1867) & Zoology (1921) & Endocrinology \\
\hline 6 & Aligarh Muslim University, Aligarh (1875) & Zoology (1906) & Development \\
\hline 7 & Panjab University, Chandigarh (1882) & Zoology (>1882) & Reprod. physiology \\
\hline 8 & Bangalore University, Bangalore (1886) & Zoology (1909) & Reproduction \\
\hline 9 & Allahabad University, Allahabad (1887) & Zoology (1906) & Reprod. toxicol., Endocrine disruption \\
\hline 10 & Ind. Vet. Res. Inst., Izatnagar (1889) & Anim.genet.(1941) & Livestock reproduction \\
\hline 11 & Ind. Inst. of Sci., Bangalore (1909) & Biochemistry (1921) & Development \\
\hline 12 & Banaras Hindu University, Varanasi (1916) & Zoology (1921) & Dev., Implantation, Early pregnancy \\
\hline 13 & University of Mysore, Mysore (1916) & Zoology (1960) & Reprod. Physiol., Development. Fertility \\
\hline 14 & University of Delhi, Delhi (1922) & Zoology (1947) & Reproduction. Endocrine disruption \\
\hline 15 & Nagpur University, Nagpur (1923) & Zoology (1963) & Reprod. Physiol. \\
\hline 16 & Seth G. S. Med. Coll., Mumbai (1926) & Reprod. physiol.(1965) & Reproduction, Fertility research \\
\hline 17 & Dr. B.R. Ambedkar Uni., Agra (1927) & Zoology (1981) & Mol. cell boil. Endocrinology \\
\hline 18 & Annamalai Uni., Chidambaram, (1929) & Zoology (1931) & Endocrinology \\
\hline 19 & Ind. Inst. of Chem.Biol., Kolkata (1935) & Cell boil.\& physiol. & Reprod. Physiol. \\
\hline 20 & University of Rajasthan, Jaipur (1947) & Zoology (1960) & Reproduction. Fertility, Contraceptive res. \\
\hline 21 & Karnatak University, Dharwad (1949) & Zoology (1959) & Dev., Early pregnancy, Reprod, toxicol. \\
\hline 22 & Cent. Drug Res. Inst., Lucknow (1951) & Endocrinol div.(1965) & Reprod. endocrinol., Reprod. toxicol. \\
\hline 23 & Ind. Cancer Res. Inst., Mumbai (1952) & Biology division & Reprod. physiol., Endocrinol. \\
\hline 24 & All Ind. Inst of Med.Sci. New Delhi (1956) & Reprod. boil. (1966) & Reprod. endocrinol., Fert. res. \\
\hline
\end{tabular}

Abbreviation: MRDR, mammalian reproduction and development research; SL No., serial number.

\#Universities/Institutions listed belong to the period between 1830-1960. 
TABLE 2

\section{INDIAN UNIVERSITIES/INSTITUTIONS INVOLVED IN RESEARCH ON MAMMALIAN REPRODUCTION AND DEVELOPMENT (HISTORICAL TO CONTEMPORARY PERIOD\#)}

\begin{tabular}{|c|c|c|c|}
\hline SL No. & University/Institute (Year of establishment) & Departments Involved in MRDR & Area of research \\
\hline 1 & Ind. Veter. Res Inst, Izatnagar (1889) & Animal reproduction & Livestock reprod., Early dev. \\
\hline 2 & Ind. Inst. of Sci., Bangalore (1909) & MRDG & Pre-implantation dev., Hum.emb. biomarkers \\
\hline 3 & Nat. Dairy Res. Inst, Karnal (1923) & Animal biotechnology & Embryo biotechnol., Fert. Res., ART \\
\hline 4 & Seth G. S. Med College, Mumbai (1926) & Reproductive physiology & Reprod. Fertility research \\
\hline 5 & Ind. Inst. of Chem. Biol. Kolkata (1935) & Cell biology \& physiology & Placental dev. Trophoblast boil. \\
\hline 6 & Cent. Drug Res. Inst. Lucknow (1951) & Endocrinology division & Reprod. toxicol. \& implant. boil. \\
\hline 7 & Ind. Cancer Res. Cent. Mumbai (1952) & Experimental embryology & Reprod. cancer boil., Development \\
\hline 8 & Kasturba Med. Coll. Manipal (1953) & Clinical embryology & Human embryogenesis, Early dev. \\
\hline 9 & All Ind. Inst. of Med. Sci. New Delhi (1956) & Reproductive biology & Reprod. endocrinol., Infertility \\
\hline 10 & Nat. Inst. for Res. in Reprod. Health, Mumbai (1970 & Primate biology division & Endometrial \& Implantn. biol \\
\hline 11 & Nat. Inst. of Fam. Plann. New Delhi (1977) & Biomedical division & Reprod. health \\
\hline 12 & Cent.for Cell. \& Mol. Biol. Hyderabad (1977) & Reprod. unit \& LaCONES & Infertility, Dev. genet., ART in big cats \\
\hline 13 & University of Hyderabad, Hyderabad(1974) & Animal biology & Reprod. endocrinol. \& toxicol. \\
\hline 14 & Int. Cent. for Gen. Eng. \& Biotech. New Delhi (1983) & Medical biotechnology & Mammalian boil. \\
\hline 15 & Nat. Inst. of Immunol. New Delhi (1982) & Life sci. \& biotechnology & Trophoblast dev. \& differentiation \\
\hline 16 & Rajiv Gandhi University, Itanagar (1984) & Zoology & Herbal reprod. med. \& contraception \\
\hline 17 & Rajiv Gandhi Cent. for Biotech.,TV'puram (1990) & Sperm-/embryo-Omics unit & Fert. Spermatogenesis \& implantation boil. \\
\hline
\end{tabular}

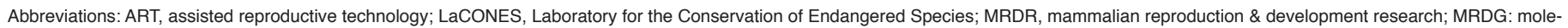
cular reproduction development \& genetics; SL No., serial number.

\# Universities/Institutions listed belong to the period between 1880s through 1960s (as listed in Table 1) and until the present time.

sities and institutes. Accessible reports indicate that, since the mid-1880s, several national and state funded universities and a few private institutes began departments and centres with zoology and biology programs with the purpose of basic education (Table 1; Vale and Dell, 2009) but, they did not simultaneously initiate specific research on early mammalian development. In contrast, western countries pursued aggressive research in this discipline and made great discoveries. Reasons for the lack of progress in India are varied and they are discussed in the later section of this article. Historically, Indian concept of reproduction and sexuality has evolved over time dating back to over a millennium. These were expressed in the form of sculptures in mountain caves and ancient temples. Besides, they were also described in ancient literature. Because this review is solely focused on early mammalian development, we have avoided details on the ancient Indian concept of sexuality (for details, see the review article by Chakraborty and Thakurata, 2013).

Historically, a few activities in reproductive biology research took place in a few of the oldest universities and institutes (see Tables 1 and 2). Here, we list twenty four universities and institutions, believed to have initiated research on mammalian reproductive biology and development, at some time during the early part of the last century. We have segregated the list of universities and institutes belonging to the (i) historical (1830-1960) and (ii) historical through contemporary (1960s-till date) time periods in Tables- 1 and -2 , respectively.

Earliest Indian reports indicate that a few clinical observations were made on the human fetal development, arising from obstetrical findings in hospital settings (Narasimhamurty, 1948; Rao, 1948). These reports describe the malformation of foetus (Ayyar, 1949) and premature infants (Janaky, 1950), segmentation of the fetal spinal cord, brain developmental disorders (Rao, 1946, 1948) and ovarian cyst formation (Singh, 1926). During this early period, there was no experimental embryology-driven research in any mammalian species. Moreover, published later-reports indicate that research was predominantly on the reproductive biology (Sarkar, 1945; Rao, 1950) and endocrinology (Sampath kumar, 1950) of rodents and farm-animals (Vaidyanathan, 1950). These early reports do not point to the exact time as to when core developmental biology research began in India. This trend continued since the later part of 1960 s through the current period.

\section{Contemporary phase}

Since post-independence (1947), cell and developmental biology research in Indian universities and institutes was very limited. Traditionally, these establishments (Table 1) were engaged in classical disciplines like botany, zoology, animal nutrition, and taxonomy. They solely served for the purpose of under/post-graduate education. Only in the late 1960s, Indian universities and institutes (Table 2) began mammalian reproduction and development research and that too, much of it was pursued in only a few institutions and universities (Table 2). The research focused majorly on three areas viz., (i) reproduction and reproductive endocrinology, (ii) fertility and contraceptive studies and (iii) human reproductive health disorders, albeit to a limited extent. In the 1970s and through the early 1980s, there was a boost on the country's infrastructure and resource capabilities. This enabled many biologists to study cells and tissues in the developmental biology context. Consequently, major research took place primarily with the endocrine physiology and reproductive biology areas with only a peripheral interest to study fundamental aspects of developmental biology.

A major reason for the late start of research on mammalian early development is that the Government of India (Gol), post-independence period, had majorly embarked on the nation building involving development of various socio-economic, industrial, agriculture and rural-cum-urban sectors. Relatively, the much required levels of efforts and the quantum of money for the education and research sectors in general and, building institutions dedicated to specific areas of reproduction and development research in particular has only began in the late 1960s. Later, new generation institutions 
with modern research facilities developed but, the country did not establish any dedicated research institute(s) or centre(s) on mammalian development. However, with the support of UGC, Family Planning Foundation, ICMR, ICAR and later DBT, a substantial infrastructure and research funds were invested to create centres for advanced research in reproductive biology in institutions such as IISc, AIIMS, IVRI (Izatnagar), NIRRH, CDRI, IICB and a few state universities in Jaipur, Chennai and Delhi (see Table 2). Currently, many of these and the new establishments (Table 2) have been pursuing contemporary research in various aspects of developmental biology involving a variety of laboratory animal models (basic research) and other species that are economically and ecologically important "flagship" species (applied research).

Simultaneously, the Gol (since the early 1990s), also embarked on creating enabling advanced and state-of-the-art research facilities such as cell and molecular biology laboratories, transgenic and gene targeting (knockout) facilities both for the mouse and for the farm-animals. Thereafter, high-end and high-resolution microscopic imaging national facilities were also created. These major national initiatives, in big-measures, have significantly boosted research capabilities on early mammalian development, employing a variety of high-end cell, molecular biological and genetic tools. Since then, Indian scientists began contributing to early mammalian development research with impactful outcomes (see Table 3).

India's contribution to Gamete biology and Embryo Developmental Biology

As described below, academic research contributions were made in areas of gamete biology, preimplantation embryo development, implantation biology with embryo- endometrial cross talks and placental development and differentiation. Moreover, molecular

TABLE 3

\section{IMPACT AND OUTCOME OF DEVELOPMENTAL BIOLOGY RESEARCH CONDUCTED IN INDIA}

\begin{tabular}{|c|c|c|}
\hline SL No. & Achievements & References \\
\hline \multirow[t]{12}{*}{1} & Establishment of Pluripotent stem cell lines: & \\
\hline & A. Embryonic stem cell (ESCs) lines & \\
\hline & (i) Human ESCs: & \\
\hline & 1. KIND1 \& KIND2 & Kumar et al., 2009 \\
\hline & 2. BJNhem19 and BJNhem20 & Inamdar et al., 2009 \\
\hline & 3. ReliCellhES1 or ReliCells hES1 & Mandal et al., 2006 \\
\hline & (ii) Mouse GS-2 ESC & Singh et al., 2012 \\
\hline & (iii) Buffalo ESC & Kumar et al., 2011 \\
\hline & B. Induced pluripotent stem cell (iPSCs) lines & \\
\hline & (i) Human iPSCs (CSCRi005-A) & Manian et al., 2018 \\
\hline & (ii) Mouse iPSCs & Makala et al., 2013 \\
\hline & (iii) Mouse N9-iPSCs & Seshagiri, 2011; Abbey et al., 2019 \\
\hline \multirow[t]{4}{*}{2} & Development of GM mouse models. & \\
\hline & $\begin{array}{l}\text { (i) EGFP-transegenic "green" mice (GU2 \& } \\
\text { GU3) }\end{array}$ & Devgan et al., 2003 \\
\hline & (ii) $\beta$-Casein KO-Mice & Sathish Kumar et al., 1994 \\
\hline & (iii) Spermato-transgenesis. & Dhup and Majumdar, 2008 \\
\hline \multirow[t]{7}{*}{3} & Generation of " the first" progeny by ART & \\
\hline & (i) Cloned buffalo calf (Garima ) & Shah et al., 2014a \\
\hline & (ii) IVF Cattle calf (Holi) & Saini et al., 2015 \\
\hline & (iii) IVF goat & Malakar et al., 2007 \\
\hline & (iv) IVF buffalo (Pratham) & Madan et al., 1991 \\
\hline & (v) Wild animal species (Black buck) & Sontakke et al., 2009 \\
\hline & (vi) IVF human baby (Durga \& Harsha) & $\begin{array}{l}\text { Mukherjee et al., 1978; Hinduja } \\
\text { \&Anand Kumar, 1988 }\end{array}$ \\
\hline
\end{tabular}

Abbreviations: ART, assisted reproductive technology; EGFP, enhanced green fluorescent protein; IVF, in vitro fertilization; NDRI, National Dairy Research Institute; SL No., serial number. regulators involved in the management of human fertility were also investigated. While specific details on the research contributions of individual Indian scientists in the area of early mammalian development is beyond the scope of this article, in the following section, a brief overview and a glimpse is provided on research profiles of India's mammalian developmental biology.

\section{Gamete development and function}

Research on gametogenesis was initiated in mid part of the last century. Studies were mainly on gamete physiology and regulation of gametogenesis and fertility control measures in terms of promoting or inhibiting fertilization using rodents (Raj and Moudgal, 1970; Gaur and Talwar, 1975; Talwar et al., 1979) and non-human primate models (Moudgal et al., 1971; Anand Kumar et al., 1980,1982). Experimental approaches involved gonadectomy models (Rao and Talwar, 1972; Lohiya and Dixit, 1974), reproductive endocrinology (Mukku and Moudgal, 1970; Singh et al., 1971), in vitro culture of reproductive tissues and their derived cell types (Talwar and Sharma, 1975; Paul et al., 1978) and reproductive toxicological studies (Kar et al., 1967). Besides, work was also carried out on screening of Indian plants for antifertility effect (Satyavati, 1984) and on endocrine disruptors (Batra, 1966). During later part of the last century and the early part of this century, India contributed to the area of spermatogenesis and sperm function involving the molecular regulation of male germ (stem) cell development and differentiation (Mitra and Shivaji, 2004; Seshagiri et al., 2007; Parab et al., 2015; Dumasia et al., 2016) and the ontogeny of differentiation-associated signalling systems during germ cell development (Chandrasekhar et al., 2011; Bhattacharya et al., 2012; Majumdar et al., 2012).

Using rodent models and the human, Indian scientists contributed to the understanding of the capacitation-associated changes in sperm protein phosphorylation and their functional significance in sperm hyper-activation phenomenon (Ain et al., 1995, 1999; Mitra and Shivaji, 2004; Mariappa et al., 2006; Seshagiri et al., 2007; Mariappa et al., 2010; Chandrasekhar et al., 2011; Sagare-Patil and Modi, 2017; Sagare-Patil et al., 2017). Besides, the functional significance of progesterone and HSP90 involved in sperm hyper-activation was determined (Sagare-Patil et al., 2017) and the molecular causes of male factor infertility (Majumdar et al., 2012; Basu et al., 2018). A number of infertility-associated gene mutations (known and novel ones) were determined (Suryavathi et al., 2008; Kattri et al., 2011; Indu et al., 2015; Colaco and Modi, 2018; Sudhakar et al., 2018). Besides, the significance of genomic imprinting, its expression and those of estrogen receptors (ESR1 and ESR-2) during spermatogenesis and sperm function was established (Dumasia et al., 2016; Kumar et al., 2018).

In contrast to studies on male germ cell biology, research on ovarian development had only been very sparse. Investigators examined genetic polymorphisms associated with a few ovarian endocrine disorders, associated with aberrations in follicular development and ovulation in the human (Ambekar et al., 2013). Experimental systems were established for the ovarian follicular development using gonadotropins in order to optimize achieving multiple ovulations and production of multiple preimplantation embryos (Seshagiri et al., 2001; Sukesh et al., 2017). Regulatory mechanisms were also elucidated with respect to ovarian corpus luteum development and/or demise in farm animals (Mondal et 


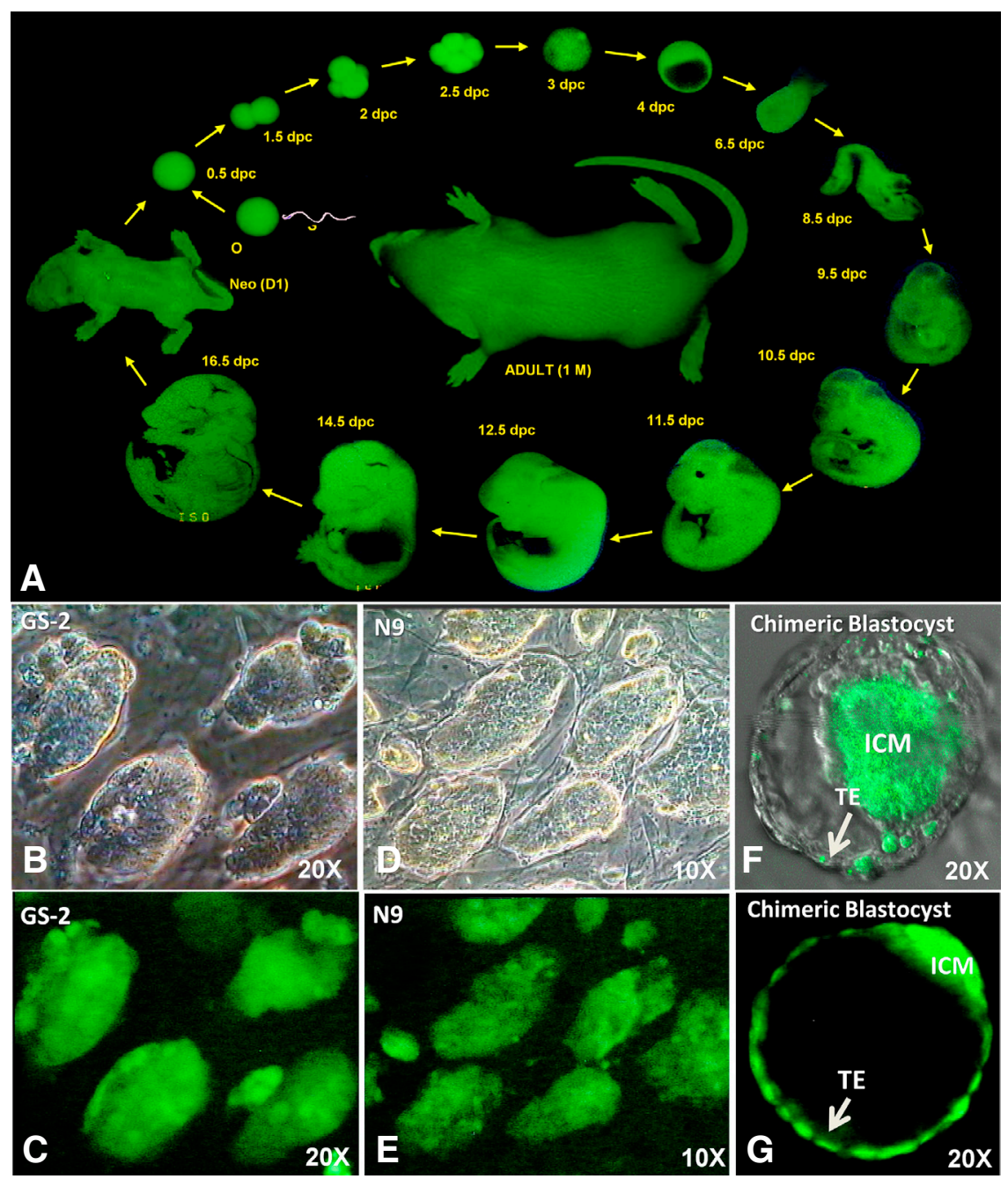

Fig. 2. Development of EGFP-expressing transgenic mouse and pluripotent stem cell lines. (A) Assessment of EGFP-expressing transgenic 'green' mouse during the entire gestation period; reproduced from Devgan et al. (2003). (B-E) In-house-derived mouse PSCsi.e., GS-2 ESC $(\mathbf{B}, \mathbf{C})$ and N9-iPSCs (D,E); reproduced from Singh et al. (2012) and Abbey et al. (2019). (B,D and C,E) Bright-field and their corresponding fluorescent images, respectively. (F,G) Representative images of (F) GS-2 ESC: wild-type 8-cell embryo reconstituted chimeric blastocyst and (G) EGFP-transgenic chimeric blastocyst. Abbreviations: EGFP, enhanced green fluorescent protein; ICM, inner cell mass; TE, trophectoderm.

steroids on endometrial receptivity during embryo implantation in various model organisms such as the mouse (Sengupta et al.,1979,1981), hamster (Prasad et al., 1960; Sengupta et al.,1983;) and the rhesus monkey (Sengupta et al.,1989).

Later, studies were carried out on the cellular and molecular regulation of fertilization (Gupta et al., 2012) and pre- and peri- implantation embryo development (Seshagiri et al., 2009; Roy and Seshagiri, 2013; Modi and Bhartiya, 2015; Roy and Seshagiri, 2016; Seshagiri et al., 2016). The expression and functional significance of oocyte ZP proteins and their functional role in the context of sperm fertilization were established both in the bonnet monkey and in the human (Jeetanandani et al.,1998; Gupta et al., 2012). In the early developmental processes, involvements of endocrine and paracrine regulators, for example sex-steroid hormone analogues/antagonist, cytokines and growth factors were investigated (Rosario et al., 2005; Ghosh and Sengupta, 2014; Seshagiri et al., 2009, 2016). Epigenetic regulatory mechanisms of imprinted genes during embryo implantation

al., 2011; Shah et al., 2014b) and primates (Priyanka et al., 2009; Sukesh etal., 2017). In farm animals, veterinary and basic scientists have optimized in vitro conditions to achieve oocyte maturation, fertilization and embryo development, particularly in economicallyprofitable species such as the cattle (Saini et al., 2015) and buffalos (Madan etal., 1991; Shah et al., 2014a). In consolidation, the above contributions have indeed boosted animal (veterinary) biotechnology research sector (Wakchaure et al., 2015). Interestingly, there was always cross- fertilization among the fields of reproductive biology, fertility regulation of laboratory and farm animals and the human (in)fertility management studies.

\section{Embryo development and function}

Mammalian experimental embryology research was initiated relatively late in India vis-a-vis western countries. Much of the Indian initial studies took place in a few institutions i.e., IISc, AIIMS, $\mathrm{NIRRH}$ and in universities at Varanasi and Jaipur (Tables 1,2). Earliest research on development involved examining anti-estrogen effect on blastocyst development and implantation (Sengupta et al., $1981,1983)$ and on the endocrinology and paracrinology of blastocyst implantation in rodents and non-human primates (Sengupta et al.,1989; Ghosh et al., 1997). Reports also showed the role of were studied (Kedia- Mokashi et al., 2011; Bhusane et al., 2016). Interesting insights were also provided into the post-implantation development of embryos and the molecular regulation of implantation and decidualization (Nimbkar-Joshi, etal., 2015; Padmanabhan and Laloraya, 2016; Mohan et al., 2018). Recently, one of the developmental pattern formation-associated genes viz., HOXA10 was shown to be involved in trophoblast invasion and embryo implantation (Ashary et al., 2018; Godbole et al., 2017). Also, in the context of trophoblastic cell differentiation (Ain et al., 2006; Rosario et al., 2009; Modi et al., 2012; Gupta et al., 2016) and placental development (Shankar and Rao, 1998; Radhakrishnan et al., 2006; Kedia-Mokashi et al., 2015; Chakraborty and Ain, 2018), the associated regulatory cell signalling pathways were investigated.

In the farm animal reproductive biotechnology domain, a number of important developments took place, in terms of bovine follicular and oocyte maturation (Sontakke et al., 2012) sperm cryopreservation technologies (Sontakke et al., 2004; Umapathy et al., 2007a) and embryo development systems (Madan et al., 1991). These leads have greatly augmented reproductive outcomes of farm animals contributing to the nation's livestock growth. Spinoff of these achievements was judiciously applied to the conservation of endangered mammals, mainly Indian big cats and ungulates (Shivaji et al., 2003; Sontakke et al., 2004; Umapathy et al., 2007a; 
Fig. 3. Portraits of the earliest Indian Pioneers involved in in vitro fertilization combined with embryo transfer technology to produce test-tube babies. (A) Dr. Subhash Mukherjee, the architect of India's first (Asia's first) test-tube baby "Durga" (3rd Oct, 1978) born in Calcutta, India (source: drsubhasmukherjee.com). (B) Dr. Indira Hinduja, the architect of India's first scientifically documented test-tube baby "Harsha" (6 $6^{\text {th }}$ Aug, 1986) born in Bombay, India (source: Rev. Dhawale, 2014).
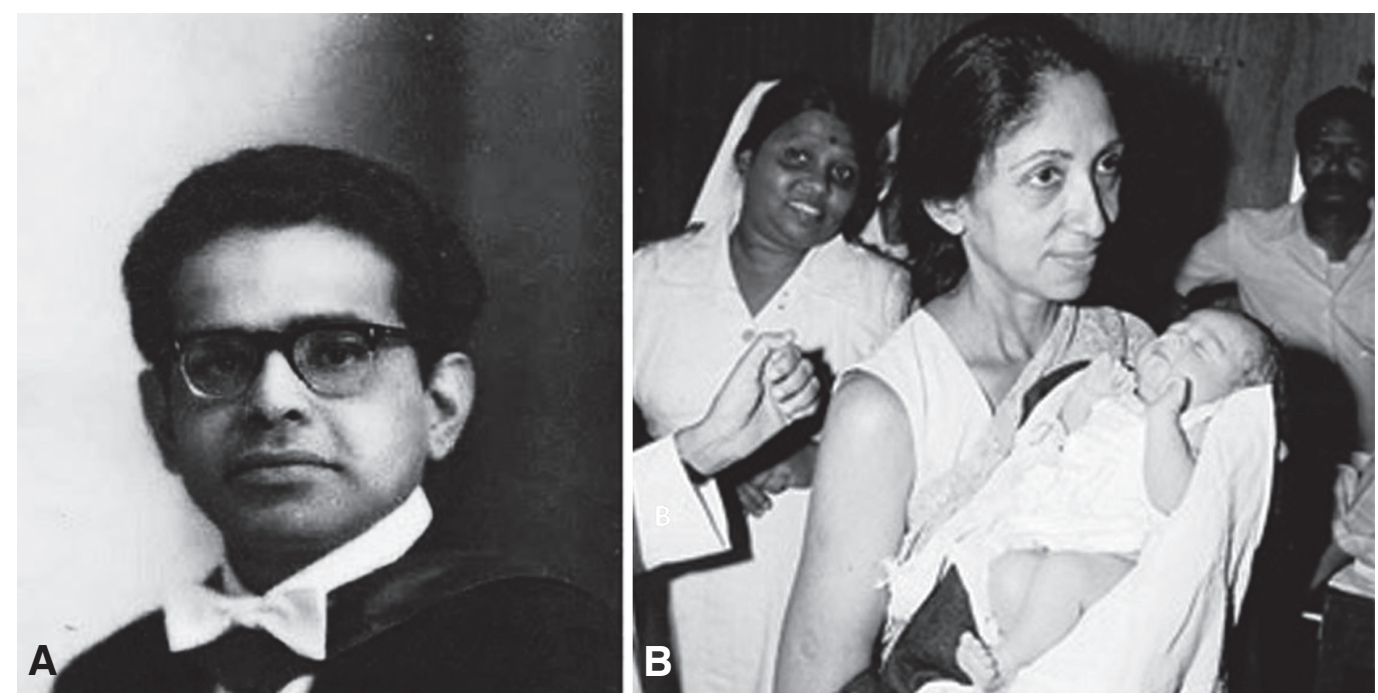

Sontakke et al., 2009). Moreover, many non-invasive method and tools were developed for measurement of biomarkers and hormone metabolites (Umapathy et al., 2007b; Kumar et al., 2014; Ghosal et al., 2012, 2013; Pokharel et al., 2017). These achievements have enabled Indian scientists to monitor reproductive- and stress- status of endangered animals endemic to India, for example, Asian elephants.

For more than a couple of decades, we have been studying early mammalian development particularly with three dynamic developmental phenomena viz., (i) sperm hyper-activation involving molecular dissection of capacitation-associated sperm protein tyrosine phosphorylation changes critical for sperm fertilization (Ain et al., 1999; Mariappa et al., 2006; Seshagiri et al., 2007; Mariappa et al., 2010), (ii) cellular and molecular regulation of development and hatching of blastocysts (Seshagiri et al., 2003, 2009,2016 ) and (3) establishment of blastocyst-derived embryonic stem cell (ESC) lines (Devgan and Seshagiri, 2003; Devgan et al., 2003) and the cell lineage-specification and functional differentiation (Verma et al., 2017). We established the first Indian EGFP-expressing transgenic green mouse (GU-2 and GU-3) lines (Singh et al., 2012) and subsequently, derived two PSC lines viz., the GS-2 ESC (Singh et al., 2012) and the N9 iPSC (Abbey et al., 2019) lines. Figure 2 highlights the EGFP transgene-expressing GU-2 mice with at its various stages of embryo development, the PSC mouse lines generated and the ESC-reconstituted chimeric mouse embryo produced. These research resources are being used by us as well as by others having our resources, elsewhere in the country.

Continuing our research with regard to peri-hatching developmental events, we systematically examined the expression and function of blastocyst hatching promoting and enabling molecular regulators and the associated zonalysins viz, cathepsins, required for hatching (Mishra and Seshagiri, 2000; Sireesha et al., 2008). Recently, we showed the critical functional roles of COX-2 (Roy and Seshagiri, 2013) and NF- $\alpha B$ (Roy and Seshagiri, 2016) in blastocyst development and hatching. One of the striking cell biology phenomena we demonstrated was the timed-appearance of trophectodermal projections during the hatching process with the intimate association of hatching-enabling molecular regulators examined (Seshagiri et al., 2009). Many of these exciting findings have immense clinical relevance in the context of human blastocyst development and implantation, potentially leading to a viable and successful pregnancy outcome.

\section{Impact of early mammalian development research in India}

India's contribution in developmental biology research, though modest, have had significant impact (see Table 3) in terms of (i) understanding basic biology of gamete and embryo development and function (Seshagiri et al., 2007,2009; Chandrashekar et al., 2011; Dumasia et al., 2016; Seshagiri et al., 2016; Kumar et al., 2018), (ii) establishing genetically modified mouse models (Sathish Kumar et al.,1994; Devgan et al., 2003; Devgan and Seshagiri, 2003; Dhup and Mujumdar, 2008), (iii) derivation of PSC lines (Mandal et al., 2006; Kumar et al., 2009; Inamdar et al., 2009; Singh et al., 2012; Kumar et al., 2011; Manian et al., 2018; Abbey et al., 2019) and (iv) using ART, generation of mammalian progeny (Shah et al., 2014a; Saini et al., 2015), including humans, by ART approaches (Mukherjee et al., 1978; Hinduja and Anand Kumar, 1988; see also Table 3).

These achievements particularly with the current availability of immortalized cell lines from reproductive tissues and the PSC lines are expected to further enhance the capacity of early mammalian development research endeavours in the country. In view of the national need to boost animal biotechnology research, in the last four decades, ICAR, CSIR and the DBT have provided major funding in order to improve fertility and enhance production of economically-profitable elite-breeds of farm animals. Generally speaking, the most significant impact, arising out of any early development research, is the birth of "test tube" progeny (conception in dishes). In this regard, India is credited to have produced world's first

(i) cloned buffalo (Shah et al., 2014a) and a calf via IVF-ET (Saini et al., 2015). Excitingly, Indian scientists also produced one of the endangered species viz., "spotty", the spotted deer (Sontakke et al., 2009). Much of these achievements in reproductive biotechnology have been possible with enabling funding and infrastructure support systems of the Gol. India will greatly benefit if the gene-modification and transgenic technology approaches 
are exploited in the context of farm animals, in term of production of elite breeds and for bio-pharmaceuticals. This is possible with the support of Gol, its national institutions and jointly with animal biotechnology private entrepreneurs.

Another aspect that requires attention in the Indian context is the primate research and its contribution to early developmental biology. Earlier periods (1970s and 1980s) have contributed substantially to primate reproduction research (Moudgal et al., 1971; Anand Kumar et al., 1980,1982; Seshagiri and Adiga, 1987). However, in the last decade, with the exception of a few studies (Rosario et al., 2005; Ganguly et al., 2008; Priyanka et al., 2009; Sukesh et al., 2017), the pace of primate research has rapidly diminished and it is almost stopped. Over time, the trajectory of primate research activity had several road blocks. This is owing to various reasons such as (i) dwindling numbers of experimental primatologists, (ii) unsustainability of cost-intensive primate research facility, (ii) changes in national policies- priorities of research resources, (iv) sensitivities associated with non-feral primates being housed in research establishments, (v) stringent measures in seeking ethics approvals to conduct research on non-human primates and (vi) such other national-societal and public concerns. Nevertheless, not-with-standing these facts, non-human primate (biomedical) research can indeed address a number of human (reproductive) health problems. Ironically, India is uniquely endemic to one of the largest native primate resources. It is hoped that in the immediate future, a re-visit is required to boost primate research with a flexible and pragmatic planning, with the involvement of (inter)-governmental and private-biotechnology $R$ \& D sectors.

Despite this India-specific limitations on primate reproduction and development alluded to above, it is remarkable that India contributed to a land-mark achievement and the capability to produce one of the first IVF human-primate "test tube" baby (Mukherjee et al., 1978; Hinduja and Anand Kumar, 1988). Arising out of the reproduction and development (clinical) research capabilities is the consistently successful generation of several of "test tube" babies by ART. Therefore, it is desirable to describe India-context-wise additional aspects pertaining to ART and birth of humans in the following dedicated section.

\section{Human development and assisted reproductive technology (ART) in India}

The most notable contribution is the $1^{\text {st }}$ human IVF baby "Durga" birth in India (Mukherjee et al., 1978; Anand Kumar et al., 1986; Anand Kumar, 1997; Tables 3-4). Its timing indeed coincided with the birth of the world's $1^{\text {st }}$ test tube baby, "Louise Joy Brown" (Steptoe and Edwards, 1978). While the birth of the India's $1^{\text {st }}$ IVF baby "Durga" was achieved by Dr. Subhash Mukherjee (Fig. 3A), almost after about eight years, Drs. Indira Hinduja (Fig. 3B) and TC Anandkumar (Fig. 4) were credited to have achieved the next and the earliest scientifically documented IVF baby "Harsha" (Anand Kumar et al., 1986; Hinduja and Anand Kumar, 1988). These early India's achievements, nevertheless, witnessed varied views and debates (Anand Kumar, 1997; Dhawale, 2014; Bharadwaj, 2016). The genesis of India's earliest human IVF-births, its publicity in the 1980 s and with a few visits to India of Prof. Robert G. Edwards, the 2010 Nobel Prize awardee, (Fig. 4) have opened up a huge research scope and a revolution in the treatment of human infertility in India. Ironically, this advancement has failed to catch up with research on human reproduction and development.

Strikingly, India has been one of the world's leading countries contributing to human "test-tube" babies through ART (Malhotra et al., 2013). It is estimated optimistically that close to a million IVF babies are born in India contributing to approximately one fifth-sixth of babies globally born (current estimate: approx. 6 million) by ART approaches (Biovin et al., 2007; Bharadwaj, 2016). India has in fact made deep inroads into medical tourism in reproductive medicine, providing a whole range of sophisticated ART approaches. Table 4 provides an overview of the current status on human embryo development technologies achieved globally and its timing of comparison with the practices in India. In terms of providing the state-of-the-art ART technologies, India has not lagged behind the western countries and it has always caught up with the rest of the world (Table 4). This flourishing infertility management health care enterprise has been constantly growing. Ironically, India is unable to catch up with the core-research on early human development

Fig. 4. A group photograph showing embryologists involved in an informal discussion. From left to right: Dr. Tiruchirapalli C. Anand Kumar, Prof. Polani B. Seshagiri, Dr. Rajiv Mehta and Prof. Robert G. Edwards. The picture was taken at the residence of TCA during one of the visits of RGE to Bangalore, India (January, 2001). Robert Edwards was awarded the 2010 Nobel Prize for Physiology or Medicine for developing in vitro fertilization-embryo transfer technology to treatinfertility in women.

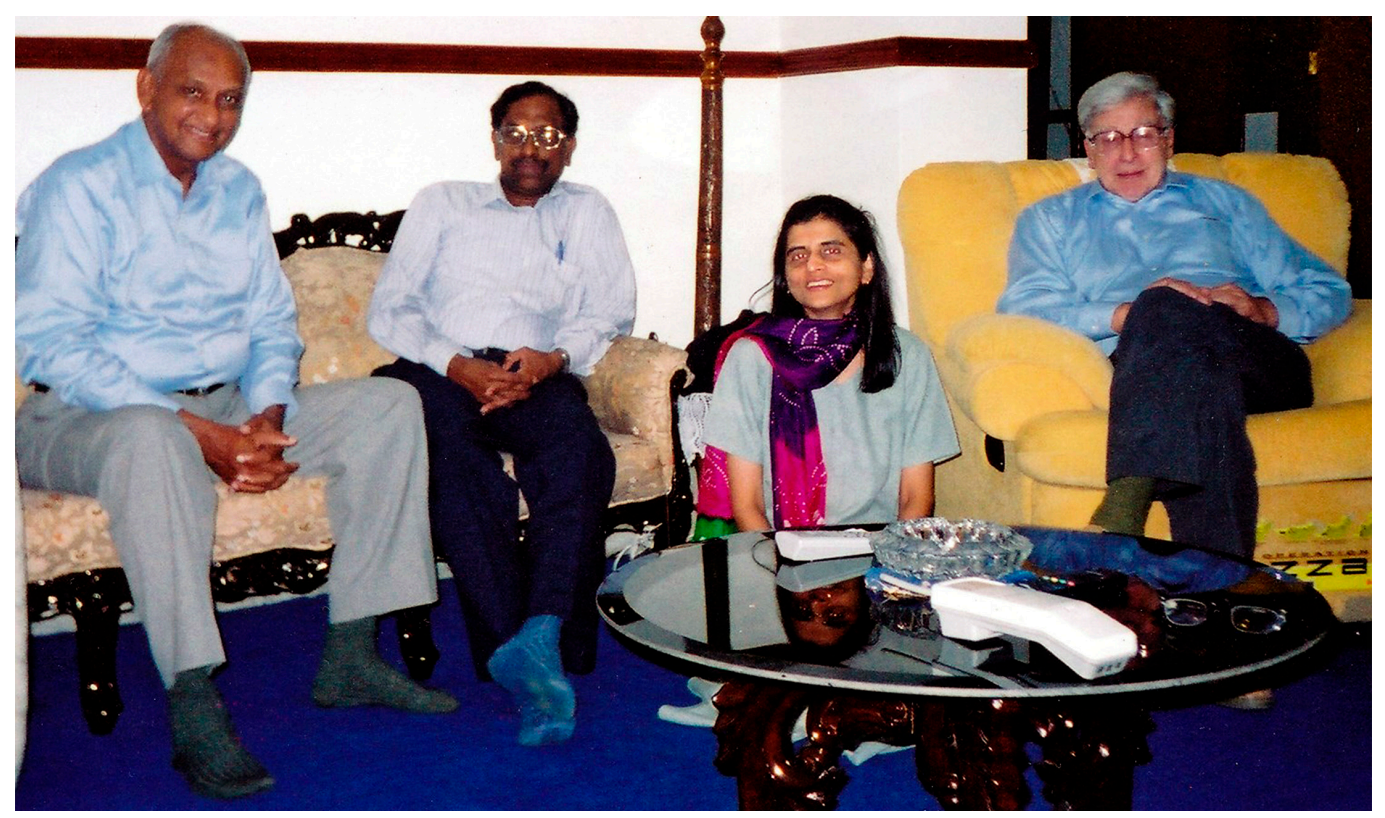


TABLE 4

\section{STATUS OF EARLY HUMAN EMBRYO DEVELOPMENT RESEARCH ACHIEVED IN THE ART SECTOR}

\begin{tabular}{|c|c|c|c|}
\hline \multirow[b]{2}{*}{ SL No. } & \multirow[b]{2}{*}{ Activity } & \multicolumn{2}{|c|}{ Earliest reports } \\
\hline & & Global & India \\
\hline \multirow[t]{2}{*}{1} & Gonadotropins and endocrine & Trounson et al., 1981; Fleming et al.,1982 & Mukherjee, et al., 1978 \\
\hline & regulators used in ART & Porter et al., 1984 & \\
\hline 2 & IVF Technique & Edwards et al.,1966 & Mukherjee et al, 1978 \\
\hline \multirow[t]{6}{*}{3} & Live births by: & & \\
\hline & (a) Fresh IVF-ET & Steptoe \& Edwards, 1978 & --- \\
\hline & (b) Cryopreserved-ET & Trounsan \& Mohr, 1983 ; Mukherjee et al.,1978 & Hinduja and Anand Kumar, 1988 \\
\hline & (c) Assisted-hatching -ET & Cohen et al., 1990 & Parikh et al., 1996 \\
\hline & (d) ICSI-ET & Palermo et al.,1992 & --- \\
\hline & (e) Vitrified-ET & Gordts et al., 1990 & --- \\
\hline 4 & Embryo quality score practice & Scoott, 2003; Gardner and Schoolcraft, 1999a,b & (Protocol. Of Gardner and Schoolcraft, 1999a,b) \\
\hline 5 & Embryo biopsy \& PGS & Handyside et al.,1989; De Boer et al., 2002 & Selvaraj et al., 2016 \\
\hline 6 & Embryo viability biomarkers & Gardner and Schoolcraft, 1998 & Seshagiri et al., (unpublished) \\
\hline 7 & Babies born till date (through ART) & 5 Million - Boivin et al., 2007 & 1 Million \\
\hline
\end{tabular}

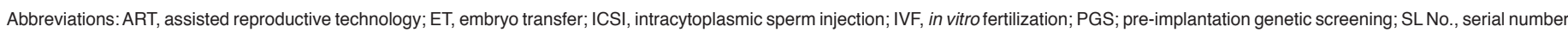

research that could provide mitigating strategies to overcome early embryonic loss and infertility.

However, India has not caught up with a few new and exciting ART approaches, for example tri-parental origin of offspring (Amato et al., 2014) and genome editing of babies (Meiliana et al., 2017). A number of reasons could be attributed to this such as the limitation and/or lack of expertise in gamete-derived organelle micromanipulation, non-availability of other sub-cellular and molecular techniques, the lack of sufficient number of patient-pool and the cost-factor. Besides, a major stickling issue in ART practices in the Indian context is the surrogacy. Though the Indian Surrogacy (Regulation) Bill was passed in 2016, with its own share of controversies, the Gol has recently banned commercial surrogacy in order to stop exploitation of vulnerable and socio-economically poor women, with their reproductive health and child-bearing capacity being compromised (see the review article by Rao and Ahmad Khan, 2017). In this regard, the Department of Health ResearchICMR has been promulgating and legitimizing the use of approved ART approaches, including the development and management of national registry. Sooner this is brought up, better it is for India to legalize the approved ART practices, including surrogacy being followed in infertility clinics.

\section{India requires a research program on human reproduction and development}

While the above described examples of achievements, in animal embryo biotechnology and human procreation strategies, are highly significant in its own measure, the quantum of research output, admittedly, is grossly inadequate and, it is not commensurate to what other western countries have been contributing thus far. In this context, an aggressive and a robust national program on human reproduction and development is urgently required.

Notably, India is second only to China in terms of the most populous country with an estimate of 1.35 billion people and it is on the rise (WPP, 2019). Associated with this massive growth and the socio-economic and environmental and ecological burdens and challenges, life-style disorders have been on the rise in the Indian population. This is particularly affecting individuals in the prime-reproductive age group and the working-class segment.
They are burdened with a huge impact on their poor reproductive health status. These include impaired gonadal development and functions, aberrant reproductive endocrine disorders, life-style diseases-associated sub/in-fertility disorders and reproductionassociated genetic disorders. To mitigate these, there is an urgent need to understand cellular and molecular controls of early human development and in applicable human surrogate animal models. There is a need to develop diagnostic methods and interventional therapeutic strategies. Besides, enhanced translational research capacities are required. All these are hugely possible in India in view of the enabling systems in place. Besides, India has a huge availability of precious clinical reproductive tissue resources, i.e., "spare" reproductive tissues and/or gametes/embryos; they could be potentially and judiciously used for research, with informed donor consent and IEC approvals.

\section{How can India internationally-catch up with developmental biology research}

First, there is a critical need for Indian scientists to contribute towards basic and translational research on early mammalian (human) development with particular emphasis on human reproductive health. In academia, at this time, research in developmental biology is carried out only in select-institutions such as IISc, NIIRRH, AIIMs, NII, CCMB, RGCB, to indicate a few. Central and state universities should be empowered to expand programs on teaching and research in developmental biology discipline. There should be policies to encourage inter-institutional and inter-national collaborations on early development research with enabling resource provisions.

Second, although a few researchers are active in this discipline of developmental biology, India is yet to achieve a much required "critical mass" in early development and embryology and developmental biology research. Based on the published literature on mammalian development and the websites of established institutes engaged in this discipline, it appears that only about 15-20 investigators are involved in mammalian developmental biology research. Besides, in the last five decades, the number of India-originated publications in this core-discipline is only about 300 plus. This reflects a highly diminished state of India's contribution in developmental biology research involving mammalian species. This is despite the avail- 
ability of a sizable number of freshly qualified (post)graduates and $\mathrm{PhD}$ degree holders in the "young" India population.

Third, there are no established dedicated organizations for developmental biology research. Ironically, this discipline does not gain importance as one of the dedicated centres in biological or life sciences in any establishments. There is an urgent need to implement various strategies to augment this important research discipline in order to expand the scope of research in modern developmental biology and reproductive medicine research in India. It is not a big-ask, if the Gol establishes a few national Institutes dedicated to human reproduction and development.

Lastly, another strategy to boost the activity is to vitalize and empower professional societies to make a strong pitch to Gol policy makers. Learned scientists and stake holders have indeed initiated a few Indian societies to foster cell and developmental biology research. These include Indian Society of Cell Biology (ASCB, 1975), Indian Society of Developmental Biology (ISDB, 1977) and Indian Society for Study of Reproduction and Fertility (ISSRF, 1988). In reproductive medicine branch, the two societies of relevance are the Indian Society for Assisted Reproduction (ISAR, 1991) and Academy of Clinical Embryologists (ACE, 2011). These professional organizations, in consultation with $\mathrm{Gol}$ and willing-philanthropists could raise funds that could substantially boost much needed India's R \& D capabilities on early mammalian (human) development program and, its potential translation to manage human development and reproductive health issues.

\section{Conclusions}

In India, the genesis of early mammalian development research could be traced back to the mid-part of the previous century. Initial research was on reproductive biology and fertility regulation programs. They contributed to basic understanding of development using various mammalian model organisms. Later, Gol provided major inputs on infrastructure development to facilitate modern cell and developmental biology research in public funded Institutes and universities. Coupled with this, new and overlapping generations of scientists numbers engaged in reproduction and development research have grown. This has produced significant progress in reproduction and development research discipline and it contributed to cellular and molecular regulation of gametogenesis and early embryogenesis. Now, India is positioning well with a good knowledge-base, technical expertise and a high-end research facility to majorly embark on mammalian reproduction and development research programs. Desirably, this could be augmented by Gol in terms of (i) strategic new initiative in this research discipline with massive infusion of research funds, (ii) establishment of dedicated institutions for early mammalian (human) development and (iii) encouragement of national and international collaborative programs. In the future, these major initiatives would have huge impact in this discipline of biology with a huge translational potential in animal biotechnology, clinical translational research involving stem cells, human reproduction and development and lastly, in bio-pharma and biotech industry sectors, involved in clinical diagnostics and product development.

\section{Acknowledgement}

The authors wish to thank funding support from the Gol funding agencies: $D S T, D B T$ and the ICMR, for undertaking early mammalian development research for over 25 years in the author's laboratory; the Indian Institute of Science for providing the enabling academic atmosphere. Thanks are also due to Ms. M.S. Padmavathi for her help during the preparation of this manuscript. The authors would like to apologise to persons whose research contributions were not cited by our over-sight or ignorance.

\section{References}

ABBEY, D., SINGH, G., VERMA, I., DEREBAIL, S., KOLKUNDKAR, U., CHANDRASHEKAR, D., ACHARYA, K., VEMURI, M. and SESHAGIRI, P.B (2019). Successful derivation of an induced pluripotent stem cell line from a genetically nonpermissive EGFP-transgenic FVB/N mouse strain Cell. Reprogram. 21:270-284.

AIN, R., KONNO, T., CANHAM, L.N. and SOARES, M.J. (2006). Phenotypic analysis of the rat placenta. In Placental and trophoblast biology: Methods in Molecular Medicine I (Eds Soares MJ and Hunt JS). Humana Press, Inc. pp. 295-313.

AIN, R., JAYAPRAKASH, D., PETER, A.T., SREENIVASA, M.S., KUMAR, M. and SESHAGIRI, P.B. (1995). Pentoxifylline improves sperm capacitation and affects in vitro fertilization of oocytes in the golden hamster. Theriogenol. 44: 553-562.

AIN, R., UMA, DEVI, K., SHIVAJI, S., SESHAGIRI, P.B. (1999). Pentoxifylline-stimulated capacitation and acrosome reaction in hamster spermatozoa: involvement of intracellular signalling molecules. Mol. Hum. Reprod.5: 618-626.

AMATO, P., TACHIBANA, M., SPARMAN, M., MITALIPOV, S. (2014). Three-Parent IVF: Gene replacement for the prevention of inherited mitochondrial diseases. Fertil Steril. 101: 31-35

AMBEKAR, A, NIRUJOGI, R., SRIKANTH, S., CHAVAN., S, KELKAR, D., HINDUJA, I., ZAVERI, K., PRASAD, T.S.S., HARSHA, H., PANDEY, A, and MUKHERJEE, S. (2013). Proteomic analysis of human follicular fluid: a new perspective towards understanding folliculogenesis. J. Proteomics 87: 68-77.

ANAND KUMAR, T.C, HINDUJA, I., JOSHI, S., KELKAR, M.D., GAITONDE, S., PURI, C.P, et al., (1986). In-vitro fertilization and embryo transfer in India. ICMR Bull. 16: 41-43.

ANAND KUMAR, T. C., PRAKASH A. and PRASAD, M.R.N. (1982). Ultrastructural features of the principal cell in the epididymis of the rhesus monkey. J. Biosci.4: 469-479.

ANAND KUMAR, T.C., SEHGAL, A., DAVID, G.F.X., BAJAJ J.S., PRASAD M.R.N. (1980). Effects of intranasal administration of hormonal steroids on serum testosterone and spermatogenesis in Rhesus monkey (Macaca Mulatta). Biol. Reprod. 22: 935-940.

ANAND KUMAR, T.C. (1997). Architect of India's first test tube baby: Dr Subhas Mukerji, 16 January 1931 to 19 July 1981. Curr. Sci. 72: 526-531.

ASHARY, N., TIWARI, A. and MODI, D. (2018). Embryo Implantation: War in times of love. Endocrinol. 159: 1188-1198.

AYYAR, S.R. (1949). Rare case of malformation of foetus. The Ind. Med. Gaz. 103-104.

BASU, S., ARYA, S.P., USMANI, A., PRADHAN, B.S., SARKAR, R.K., GANGULI, N., SHUKLA, M., MANDAL, K., SINGH, S., SARDA, K. and MAJUMDAR, S.S. (2018). Defective Wnt3 expression by testicular Sertoli cells compromise male fertility. Cell Tiss. Res. 371: 351-363.

BATRA, B.K. (1966). A study of reproduction \& ovarian histology in mice treated with a chemical carcinogen. Ind. J. Exp. Boil. 4: 139-143.

BHARADWAJ, A. (2016). The Indian IVF saga: a contested history. Reprod. BioMed. and Soc. Online. 2: 54-61.

BHAT, M.A., SHARMA, J.B., ROY, K.K., SENGUPTA, J. and GHOSH, D. (2019). Genomic evidence of $Y$ chromosome microchimerism in the endometrium during endometriosis and in cases of infertility. Reprod. Biol. Endocrinol. 17(22): 1-10.

BHATTACHARYA, I., PRADHAN, B.S., SARDA, K., GAUTAM, M., BASU, S. and MAJUMDAR, S.S. (2012). A switch in Sertoli cell responsiveness to FSH may be responsible for robust onset of germ cell differentiation during prepubertal testicular maturation in rats. Am. J. Physiol. Endocrinol. Metab. 303: E886-E898.

BHUSANE, K., BHUTADA, S., CHAUDHARI, U., SAVARDEKAR, L., KATKAM, R. and SACHDEVA, G. (2016). Secrets of Endometrial Receptivity: Some Are Hidden in Uterine Secretome. Am. J. Reprod. Immunol.75: 226-236.

BOIVIN, J., BUNTING, L. COLLINS J. A., and NYGREN K. G. (2007). "nternational estimates of infertility prevalence and treatment-seeking: potential need and demand for infertility medical care. Hum. Reprod. 22: 1506-1512.

CHAKRABORTY K. and THAKURATA R.G. (2013). Indian concepts on sexuality. Ind. J Psych. 55: 250-255 
CHAKRABORTY, S. and AIN, R. (2018). NOSTRIN: A novel modulator of trophoblast giant cell differentiation. Stem Cell Res.31: 135-146.

CHANDRASEKHAR, A., LALORAYA, M. and KUMAR, P.G. (2011). Modulation of nicotinamide adenine dinucleotide phosphate oxidase activity through sequential posttranslational modifications of $\mathrm{p} 22$ phagocytic oxidase during capacitation and acrosome reaction in goat spermatozoa. J. Anim. Sci. 89: 2995-3007.

COHEN, J., ELSNER, C., KORT, H., MALTER, H., MASSEY, J., MAYER, M.P. and WIEMER, K. (1990). Impairment of the hatching process following IVF in the human and improvement of implantation by assisting hatching using micromanipulation. Hum. Reprod. 5: 7-13.

COLACO, S. and MODI, D. (2018). Genetics of the human Y chromosome and its association with male infertility Reprod. Biol. Endocrinol. 14: 1-24.

COSTANTINI, R. and LACY, E. (1981). Introduction of rabbit b-globin gene into the mouse germ line. Nature 294: 92-94.

DE BOER, K., MCARTHUR, S., MURRAY, C. and JANSEN, R. (2002). First live birth following blastocyst biopsy and PGD analysis. Reprod. Biomed. Online. 4: 35

DE FELICI, M. and SIRACUSA, G. (2000). The rise of embryology in Italy: from the Renaissance to the early $20^{\text {th }}$ century. Int. J. Dev. Biol. 44: 515-521.

DEVGAN, V. and SESHAGIRI, P.B. (2003). Successful development of viable blastocysts from enhanced green fluorescent protein transgene-microinjected mouse embryos: comparison of culture media. Mol. Reprod. Dev. 65: 269-277.

DEVGAN, V., THOMAS, M., ULLAS, K.S., RAO, M.R.S. and SESHAGIRI, P.B. (2003). Embryo-culture-based generation of enhanced green fluorescent protein-transgenic mice. Biochem. Biophys. Res. Commun. 303: 994-1001.

DHAWALE, A.J. (2014). Dr. Subhas Mukherjee and India's First Test Tube Baby. Pharma Tutor. 2: 99-106

DHUP, S. and MAJUMDAR, S.S. (2008). Transgenesis via permanent integration of genes in repopulating spermatogonial cells in vivo. Nature Method 5: 601-603.

DUMASIA, K., KUMAR, A., DESHPANDE, S., SONAWANE, S. and BALASINOR N.H. (2016). Differential roles of estrogen receptors, ESR1 and ESR2, in adult rat spermatogenesis. Mol. Cell. Endocrinol.428: 89-100.

EDWARDS, R.G., DONAHUE, R.P., BARAMKI, T.A. and JONES, H.W. JR. (1966). Preliminary attempts to fertilize human oocytes matured in vitro. Am. J. Obstet. Gynecol. 96: 192-200

EVANS, M.J. and KAUFMAN, M.H. (1981). Establishment in culture of pluripotential cells from mouse embryos. Nature 292: 154-156.

FLEMING, R., ADAM, A.H., BARLOW, D.H., BLACK, W.P., MACNAUGHTON M.C. and COUTTS, J.R. (1982). A new systematic treatment for infertile women with abnormal hormone profiles. Br. J. Obstet.Gynaecol. 89: 80-83.

GANGULY, A., SHARMA, R.K and GUPTA, S.K. (2008). Bonnet monkey (Macaca radiata) ovaries, like human oocytes, express four zona pellucida glycoproteins. Mol Reprod Dev. 75: 156-166.

GARDNER, D.K. and SCHOOLCRAFT, W.B. (1998). Human embryo viability: what determines developmental potential, and can it be assessed: J. Assist. Reprod. Genet. 15: 455-458.

GARDNER, D.K. and SCHOOLCRAFT, W.B. (1999b). Culture and transfer of human blastocysts. Curr. Opin. Obstet. Gynecol. 11: 307-311.

GARDNER, D.K., and SCHOOLCRAFT, W.B. (1999a). In vitro culture of human blastocysts. In Toward Reproductive Certainty: Fertility and Genetics Beyond 1999 (Eds Jansen R, Mortimer D). Parthenon Publishing, London, pp. 378-388.

GARDNER, R.L. (1968). Mouse chimearas by the injection of cells into the blastocyst. Nature 220: 596-597.

GARDNER, R.L. and PAPAIOANNOU, V.E. (1975). Differentiation in the trophectoderm and inner cell mass. In The early development of mammals. The second symposium of the British Society for Developmental Biology. (Eds. M. Balls and A.E. Wild) Cambridge University Press. pp. 107-132.

GAUR, R.D and TALWAR, G.P. (1975). Further studies on the fertility promoting factor from human seminal plasma. Int. J. Fertil. 20: 133-136.

GHOSAL, R., GANSWINDT. A., SESHAGIRI, P.B. and SUKUMAR, R, (2013). Endocrine correlates of musth in free-ranging Asian elephants (Elephas maximus) determined by non-invasive faecal steroid hormone metabolite measurements. PLoS One.8:e84787: 1-8.

GHOSAL, R., KALAIVANAN, N., SUKUMAR, R., and SESHAGIRI, P.B. (2012). Assessment of estrus cyclicity in the Asian elephant (Elephas maximus) by measurement of fecal progesterone metabolite $5 \mathrm{a}-\mathrm{P}-3 \mathrm{OH}$, using a non-invasive assay. Gen Comp Endocrinol. 175: 100-108.

GHOSH, D. and SENGUPTA, J. (2014). Delineating the prime mover action of progesterone for endometrial receptivity in primates. Ind. J. Med. Res.140:S130-136.

GHOSH, D., NAYAK, N.R., KUMAR, P.G., DHARA, S. and SENGUPTA, J. (1997). Hormonal requirement for blastocyst implantation and a new approach for antiimplantation strategy. Ind. J. Physiol. Pharmacol. 41: 101-108.

GODBOLE, G., SUMAN, P., MALIK, A., GALVANKAR, M., JOSHI, N., FAZLEABAS A., GUPTA, S.K. and MODI, D. (2017). Decrease in Expression of HOXA10 in the Decidua After Embryo Implantation Promotes Trophoblast Invasion. Endocrinol. 158: 2618-2633.

GORDTS, S., ROZIERS, P., CAMPO, R. and NOTO, V. (1990). Survival and pregnancy outcome after ultrarapid freezing of human embryos. Fertil. Steril. 53: 469-472.

GUPTA, S.K., BHANDARI, B., SHRESTHA, A., BISWAL, B.K., PALANIAPPAN, C., MALHOTRA, S.S., GUPTA, N. (2012). Mammalian zona pellucida glycoproteins: structure and function during fertilization. Cell Tissue Res. 349: 665-678.

GUPTA, S.K., MALHOTRA, S.S., MALIK, A., VERMA, S., CHOUDHARY, P. (2016) Cell signalling pathways involved during invasion and syntialization of trophoblast cells. Am. J. Reprod. Immunol. 75: 361-371.

HANDYSIDE, A.H., PATTINSONJ,.K., PENKETHR, J., DELHANTY, J.D., WINSTON, R.M. and TUDDENHAM, E.G. (1989). Biopsy of human preimplantation embryos and sexing by DNA amplification. Lancet.18: 1: 347-349.

HINDUJA, I.N. and ANAND KUMAR, T.C. (1988). In vitro fertilization and embryo replacement in women. Nat. Med. J. Ind.1: 10-15.

INAMDAR, M.S., VENU, P., SRINIVAS, M.S., KAMINI R. and RAGHAVAN K.V. (2009). Derivation and Characterization of Two Sibling Human Embryonic Stem Cell Lines from Discarded Grade III Embryos. 423. Stem Cells Dev. 18: 423-433.

INDU, S., SEKHAR, S.C., SENGOTTAIYAN, J., KUMAR, A., PILLAI, S.M., LALORAYA, M. and KUMAR, P.G. (2015). Aberrant expression of Dynein light chain 1 is associated with human male factor infertility. Mol. Cell. Proteomics.14: 318 5-95.

JANAKY, J. (1950). Therapeutic use of vernix caseosa in care of premature infants. Gynaecologia. 130: 127-36.

JETHANANDANI, P., SANTHANAM, R., GUPTA, S.K. (1998). Molecular cloning and expression in Escherichia coli of cDNA encoding bonnet monkey (Macaca radiata) zona pellucida glycoprotein-ZP2. Mol. Reprod. Dev. 50: 229-239.

KAR, A.B., KAMBOJ, V.P., SETTY, B.S. (1967). Antispermatogenic effect of some progestational steroids in rats. Ind. J. Exp. Biol.5: 45-46.

KEDIA, N., KADAM, L., DUMASIA, K. and BALASINOR, N.H. (2016). Possible Role of Paternal Aberrant Imprinting in Placental Development: A Study in Tamoxifen Treatment Rat Mode. J. Clin. Epigenet. 2: 1-9.

KEDIA-MOKASHI, N., MUGASIMAGALAM, R., AIYAZ, M., MUKHERJEE, S. and BALASINOR, N.H. (2011). Aberrant expression of imprinted genes in post- implantation rat embryos. Life Sci. 88: 634-643.

KHATTRI, A., BHUSHAN, S.S., SIREESHA, V., GUPTA, N.J., CHAKRAVARTY, B.N. DEENDAYAL, M., PRASAD, S., SINGH, L. and THANGARAJ, K. (2011). The TNP1 haplotype - GCG is associated with azoospermia. Int. J. Androl. 34: 173182.

KUMAR, A., DUMASIA, K., DESHPANDE, S., RAUT, S. and BALASINOR, N.H. (2018). Dilineating the regulation of estrogen and androgen receptor expression by sex steroids during rat spermatogenesis. J. Steroid. Biochem, Mol. Biol. 182: 127-136

KUMAR, D., ANAND, T., SINGH, K.P., SINGH, M.K., SHAH, R.A., CHAUHAN, M.S., PALTA, P., SINGLA, S.K. and MANIK, R.S. (2011). Derivation of buffalo embryonic stem-like cells from in vitro-produced blastocysts on homologous and heterologous feeder cells. J. Assist. Reprod. Genet. 28: 679-688.

KUMAR, N., HINDUJA, I., NAGVENKAR, P., PILLAI, L., ZAVERI, K., MUKADAM, L., TELANG, J., DESAI, S., MANGOLI, V., MANGOLI, R., PADGAONKAR, S., KAUR, G., PURI, C. and BHARTIYA, D. (2009). Derivation and characterization of two genetically unique human embryonic stem cell lines on in-house-derived human feeders. Stem Cells Dev.18: 435-45.

KUMAR, V, REDDY, V, KOKKILIGADDAA, SHIVAJI, S, UMAPATHY, G. (2014). Noninvasive assessment of reproductive status and stress in captive Asian elephants in three south Indian zoos. Gen. Comp. Endocrinol. 201: 37-44.

LOHIYA, N.K. and DIXIT, V.P. (1974). Biochemical studies of the testes and sex accessory organs of the desert gerbil after vasectomy. Fertil. Steril. 25: 617-620.

MADAN, M.L., SINGLA, S.K., JAILKHANI, S. and AMBROSE, J.D. (1991). In vitro fertilization in buffalo and birth of first ever IVF buffalo calf. Proc. of the 3rd Buffalo 
Congress. Verma, Bulgaria, 15-19 May, Vol.7, pp. 11-17.

MAJUMDAR, S.S., SARDA, K., BHATTACHARYA, I. and PLANT, T.M. (2012). Insufficient androgen and $\mathrm{FSH}$ signaling may be responsible for the azoospermia of the infantile primate testes despite exposure to an adult-like hormonal milieu. Hum Reprod. 27: 2515-2525.

MALAKAR1, D., DAS1, S.K., MUKESH, M., SODHI, M. and GOSWAMI, S. L. (2007). Production of Kids from In vitro Fertilized Goat Embryos and Their Parentage Assessment Using Microsatellite Markers. Asian-Aust. J. Anim. Sci. 20: 842-849.

MALHOTRA, N., SHAH, D., PAI, R., PAI, H.D. and BANKAR, M. (2013). Assisted reproductive technology in India: A 3 year retrospective data analysis. J. Hum. Reprod. Sci. 6: 235-240.

MANDAL, A., TIPNIS, S., RAJARSHI, P., RAVINDRAN, G., BOSE, B., PATKI, A., RAO, M.S. and KHANNA, A. (2006). Characterization and in vitro differentiation potential of a new human embryonic stem cell line, ReliCellshES1. Differentiation 74:81-90.

MANIAN, K.V., BHARATHAN, S.P., MADDALI, M, SRIVASTAVA, V.M., SRIVASTAVA, A. and VELAYUDHAN, S.R. (2018). Generation of an integration- free iPSC line (CSCRi005-A) from erythroid progenitor cells of a healthy Indian male individual. Stem Cell Res. 29: 148-151.

MARIAPPA, D., SIVA, A.B., SHIVAJI, S. and SESHAGIRI, P.B. (2006). Tyrphostin-A47 inhibitable tyrosine phosphorylation of flagellar proteins is associated with distinct alteration of motility pattern in hamster spermatozoa. Mol. Reprod. Dev.73:215-225.

MARIAPPA, D., ALADAKATTI, R.H., DASARI, S.K., SRE-KUMAR,A., WOLKOWICZ, M., VAN DER HOORN, F., SESHAGIRI, P.B. (2010). Inhibition of tyrosine phosphorylation of sperm flagellar proteins, outer dense fiber protein-2 and tektin-2, is associated with impaired motility during capacitation of hamster spermatozoa. Mol. Reprod. Dev.77: 182-193.

McLAREN, A. (1992). Development of primordial germ cells in the mouse. Andrologia 24: 243-247.

McLAREN, A. (1976). Mammalian Chimaeras. Cambridge University Press, Cambridge. MEILIANA, A., DEWI, N.M. and WIJAYA, A. (2017). Genome Editing with Crispr-Cas9 Systems: Basic Research and Clinical Applications. Indones Biomed J. 9: 1-16

MEKALA SUBBA RAO, VASUNDHARA VAUHINI, USHA NAGARAJAN, SAVITRI MADDILETI, SUBHASH GADDIPATI and INDUMATHI MARIAPPAN. (2013). Derivation, characterization and retinal differentiation of induced pluripotent stem cells.J. Biosci. 38: 123-134.

MINTZ, B. (1974). Gene control of mammalian differentiation. Annu. Rev. Genet. 8: $411-470$.

MISHRA, A. and SESHAGIRI, P.B. (2000). Evidence for the involvement of speciesspecific embryonic protease in zona dissolution of hamster blastocysts. Mol. Hum. Reprod. 6: 1005-1012.

MITRA, K. and SHIVAJI, S. (2004). Novel tyrosine-phosphorylated post-pyruvate metabolic enzyme, dihydrolipoamide dehydrogenase, involved in capacitation of hamster spermatozoa. Biol. Reprod. 70: 887-899.

MODI, D. and BHARTIYA, D. (2015). Physiology of Embryo Endometrial cross talk. Biomed. Res. J. 2: 83-104.

MODI, D.N., GODBOLE, G., SUMAN, P. and GUPTA, S.K. (2012). Endometrial biology during trophoblast invasion. Front Biosci. 4: 1151-1171.

MOHAN, J.J., NARAYAN, P., PADMANABHAN, R.A., JOSEPH, S., KUMAR, P.G. and LALORAYA, M. (2018). Silencing of dedicator of cytokinesis (DOCK180) obliterates pregnancy by interfering with decidualization due to blockage of nuclear entry of autoimmune regulator (AIRE). Am. J. Reprod. Immunol. 80: 1-14.

MONDINO, D. (1478). Anothomia Mundini, Papie: Antonio de Carcano.

MONDAL, M., SCHILLING, B., FOLGER, J., STEIBEL, J.P., BUCHNICK, H., ZALMAN, Y., IRELAND, J.J., MEIDAN, R. AND SMITH, G.W. (2011). Deciphering the luteal transcriptome: potential mechanisms mediating stage-specific luteolytic response of the corpus luteum to prostaglandin $\mathrm{F}_{2}$ a. Physiol. Genomics. 43: 447-456.

MOUDGAL, N.R., MACDONALD, G.J., GREEP RO. (1971). Effect of HCG antiserum on ovulation and corpus luteum formation in the monkey (Macaca fascicularis). J. Clin.Endocrinol. Metab. 32: 579-581.

MUKHERJEE, S, MUKHERJEE, S, and BHATTACHARYA, S.K. (1978). The feasibility of long-term cryogenic freezing of viable human embryos - a brief pilot study report. Ind. J. Cryog. 3: 80.

MUKKU, V. and MOUDGAL, N.R. (1970). relative sensitivity of the corpus luteum of different days of pregnancy to LH-deprivation in the rat and hamster. Mol. Cell.
Endocrinol. 6: 71-80.

MULNARD, J. (1986). An historical survey of some basic contributions to causal mammalian embryology. Hum. Reprod. 1: 373-380.

NARASIMHAMURTY, P. (1948). An abnormal foetus. Antiseptic. 45: 409. NEEDHAM, J. (1959). A History of Embryology. New York: Abelard-Schuman.

NIMBKAR-JOSHI, S., KATKAM, R.R., KAKAR, R., SINGH, P., CHAUDHARI, U.K., MANJRAMKAR, D.D., METKARI, S.M., KHOLKUTE, S.D., PURI, C.P. and SACHDEVA, G. (2015). Proliferation and decidualization of endometrial stromal cells during embryo-attachment stage in bonnet monkeys (Macaca radiata) Cell Tiss. Res.361: 605-617.

PADMANABHAN, R.A. and LALORAYA, M. (2016). Estrogen-Initiated Protein Interactomes during Embryo Implantation. Am. J. Reprod. Immunol.75: 256-262.

PALERMO, G., JORIS, H., DEVROEY, P. and VAN STEIRTEGHEM, A.C. (1992). Pregnancies after intracytoplasmic injection of single spermatozoon into an oocyte.Lancet. 340: 17-18.

PALMITER, R.D., BRINSTER, R.L., HAMMER, R.E., TRUMBAUER, M.E., ROSENFELD, M.G., BIRNBERG, N.C. and EVANS, R.M. (1982). Dramatic growth of mice that develop from eggs microinjected with metallothionein-growth hormone fusion genes. Nature 300: 611-615.

PAPAIOANNOU, V.E. (1998). The coming of age of the transgenic era. Int. J. Dev. Biol. 42: 841-846.

PARAB, S., SHETTY, O., GAONKAR, R., BALASINOR, N., KHOLE, V. and PARTE, P. (2015). HDAC6 deacetylates alpha tubulin in sperm and modulates sperm motility in Holtzman rat. Cell Tiss. Res. 359: 665-678.

PAUL, S, JAILKHANI, B.L. and TALWAR, G.P. (1978). Isolation and functional maintenance in culture of syncytiotrophoblasts from human placenta. Ind. J. Exp. Biol. 16: 1226-1235.

PHARIKH F., KAMAT, S.A., NADKARNI S. and Arawandekar D. (1996). Assisted hatching in an in vitro fertilization programme. J. Reprod. Fertil. 50: 121-125.

POKHAREL, S.S., SESHAGIRI, P.B., SUKUMAR, R. (2017). Assessment of seasondependent body condition scores in relation to faecal glucocorticoid metabolites in free- ranging Asian elephants. Conserv. Physiol. 5: 1-14.

PORTER, R.N., SMITH, W., CRAFT, I.L., ABDULWAHID, N.A. and JACOBS, H.S. (1984). Induction of ovulation for in-vitro fertilisation using buserelin and gonadotropins. Lancet 2: 1284-1285.

PRASAD, M. R. N., ORSINI, M. W., and MEYER, R. K. (1960). Nidation in progesterone-treated, estrogen- deficient hamsters, Mesocricetus auratus (Waterhouse). Proc. Soc. Exptl. Biol. Med. 104: 48-51.

PRIYANKA, S., JAYARAM, P., SRIDARAN, R. and MEDHAMURTHY, R. (2009). Genome-wide gene expression analysis reveals a dynamic interplay between luteotropic and luteolytic factors in the regulation of corpus luteum function in the bonnet monkey (Macaca radiata) Endocrinol. 150: 1473-1484.

RADHAKRISHNAN, Y., RAMA, S., MOORTHY, A, RAO, A.J. (2006). Role of estrogen in regulation of cellular differentiation: A study using human placental and rat Leydig cells. Mol. Cell. Endocrinol. 246: 114-120.

RAJ, H.G. and MOUDGAL, N.R. (1970). Effect of anti-luteinizing hormone serum on the ovulation of rats. Nature. 227: 1344-1345.

RAO, V.S. (1946). Segmentation of the spinal cord in the human embryo. Nature.158: 628. RAO, C.K. (1950). The physiology of the rooster sperm. Ind. Vet. J. 27: 23-31.

RAO, J.S. and AHMAD KHAN, M. (2017). Surrogacy in India: Current Perspectives. Int. J. Med. Health Res. 3: 85-88

RAO, K.N. and TALWAR, G.P. (1972). Action of oestradiol-17 and cyclic AMP on the synthesis of RNA, phosphoproteins and phospholipids in the uterus of ovariectomized rats in vitro. J. Endocrinol. 54: 215-126.

RAO, V.S. (1948). The postcalcarine sulcus in the human embryo. Anat. Rec. 101: 577-579. ROSARIO, G., SACHDEVA, G., MANJRAMKAR, D.D., MODI, D.N., MEHERJI, P.K. and PURI, C.P. (2005). Endometrial expression of immunomodulatory cytokines and their regulators during early pregnancy in bonnet monkeys (Macaca radiata). Hum. Reprod. 20: 3039-3046.

ROSARIO, G.X., AIN, R., KONNO, T. and SOARES, M.J. (2009). Intrauterine fate of invasive trophoblast cells. Placenta 30: 457-463.

ROY, S.S. and SESHAGIRI, P.B. (2013). Expression and function of cyclooxygenase-2 is necessary for hamster blastocyst hatching. Mol. Hum. Reprod. 19: 838-851.

ROY, S.S. and SESHAGIRI, P.B. (2016). The NF-kB signaling system is required for blastocyst hatching in the golden hamster: Mediated by the expression of hatch- 
ing- promoting cathepsins. J. Reprod. Health and Med. 2: 74-82.

SAGARE-PATIL, V., BHILAWADIKAR, R., GALVANKAR, M., ZAVERI, K. and HINDUJA, IN. and MODI, D. (2017) Progesterone requires heat shock protein 90 (HSP90) in human sperm to regulate motility and acrosome reaction. J. Ass. Reprod. Genet. 34: 495-503.

SAGARE-PATIL, V. and MODI, D. (2017). Identification of motility-associated progesterone-responsive differentially phosphorylated proteins Reprod. Fert. Dev. 29: 1115-1129.

SAINI, N., SINGH, M.K., SINGH, K.P, MANIK, R.S., SINGLA, S.K. and PALTA, P. (2015). "Holi": India's first cattle calf produced through Ovum pick-up-IVF technology-from an aged Sahiwal cattle. Ind. J. Anim. Sci. 244-247.

SAMPATH KUMARAN, J.D. (1950). The endocrinology of the male gonad. Ind.Vet J. 26: 363-377.

SARKAR, M.N. (1945). Sterility and prevention of conception. Calcutta Med. J.42: 191- 193.

SATISH KUMAR, CLARKE, A.R., HOOPER, M.L., HORNE, D.S., LAW, A.J. R., LEAVER, J., SPRINGBETT, A., STEVENSON E. and SIMONS J. P. (1994). Milk composition and lactation of $\mathrm{f3}$-casein-deficient mice. Proc. Natl. Acad. Sci. USA 91: 6138-6142.

SATYAVATI, G. V. (1984). Indian plants and plant products with antifertility effect. Anc.Sci, Life. 3: 193-202.

SCOTT, L. (2003). Pronuclear scoring as a predictor of embryo development. Reprod Biomed. 6: 201-214.

SELVARAJ, P., SELVARAJ, K. and SRINIVASAN, K. (2016). Successful birth of South India's first twins after preimplantation genetic screening of embryos. J. Hum. Reprod. Sci. 9: 121-124.

SENGUPTA, J. and GHOSH, D. (2014). Multi-level and multi-scale integrative approach to the understanding of human blastocyst implantation. Prog. Biophys. Mol. Biol. 114: 49- 60.

SENGUPTA, J. ROY, S.K. and MANCHANDA, S.K. (1979). Hormonal control of implantation: a possible role of lysosomal function in the embryo-uterus interaction. $J$ Steroid Biochem. 11: 729-44.

SENGUPTA, J., PARIA, B.C. and MANCHANDA, S.K. (1983). Effect of an estrogen antagonist on development of blastocysts and implantation in the hamster. $J$ Exp. Zool. 221: 119-22.

SENGUPTA, J., ROY, S.K. and MANCHANDA, S.K. (1981). Effect of an anti-oestrogen on implantation of mouse blastocysts. J. Reprod. Fertil. 62: 433-6.

SENGUPTA, J., TALWAR, D., PARIA, B.C. and GHOSH, D. (1989). Is there any delta 5-3 beta hydroxysteroid dehydrogenase activity in preimplantation embryo of rhesus monkey? Ind.J. Exp. Biol. 27: 417-420.

SESHAGIRI, P.B. (2001). Molecular insights into the causes of male infertility. $J$ Biosci. 26: 429-435.

SESHAGIRI, P.B and ADIGA P.R. (1987). Pregnancy suppression in the bonnet monkey by active immunisation with chicken riboflavin carrier protein. $J$ Reprod Immunol.12: 93-107.

SESHAGIRI, P.B., ACHARYA, K.K., JAYAPRAKASHD., SATISH K.S., AND SHETTY, G. (2001). Ovarian hyperstimulation in Bonnet monkey using gondadotrophins. (Eds. Anan Kumar and Amal K. Mukhopadhyay). In Follicular growth, ovulation and fertilization: Molecular and Clinical Basis. (Narosa Editorial) p. 73-81.

SESHAGIRI, P.B., LALITHA, H.S., MISHRA, A. and SIREESHA, G.V. (2003). Embryo- endometrial proteases during early mammalian development. Ind. J. Exp. Biol. 41: 756- 763.

SESHAGIRI, P.B., MARIAPPA, D. and ALADAKATTI, R.H. (2007).Tyrosine phosphorylated proteins in mammalian spermatozoa: molecular and functional aspects. Soc. Reprod. Fertil. Suppl.63: 313-325.

SESHAGIRI, P.B., ROY, S.S., SIREESHA, G. and RAO, R.P. (2009). Cellular and molecular regulation of mammalian blastocyst hatching. J. Reprod. Immunol.83:79-84.

SESHAGIRI, P.B., VANI, V. and MADHULIKA, P. (2016). Cytokines and blastocyst Hatching. Am. J. Reprod. Immunol. 75: 208-217.

SHAH, S.M., SAINI, N., ASHRAF, S., KAUR, R. and CHAUHAN, M.S. (2014a). Stem Cell and Cloning Research in Farm Animals: A Special Focus on Buffalo. MGM J. Med. Sci. 1: 163-173.

SHAH, K.B., TRIPATHY, S., SUGANTHI, H.. and RUDRAIAH, M. (2014b). Profiling of luteal transcriptome during prostaglandin $\mathrm{F} 2$-alpha treatment in buffalo cows:Analysis of signaling pathways associated with luteolysis. PloS One 9:e104127.1-18.
SHANKAR, Y.G and RAO, A.J. (1998). Endocrine function of the human placenta PINSA. B64: 35-50.

SHIVAJI, S., KHOLKUTE, S.D., VERMA, S.K., GAUR, A., UMAPATHY, G., SINGHA SONTAKKE, S., SHAILAJA, K., REDDY, A., MONIKA, S., SIVARAM, V., JYOTSNA B., BALA, S., AHMED, M.S., BALA, A., CHANDRASHEKAR, B.V., GUPTA, S., PRAKASH, S. and SINGH, L. (2003). Conservation of wild animals by assisted reproduction and molecular marker technology. Ind. J. Exp. Biol. 41: 710-723.

SINGH, G., TOTIGER, T.M. and SESHAGIRI, P.B. (2012). Successful derivation of EGFP-transgenic embryonic stem cell line from a genetically non-permissive FVB/N mouse. Am. J. Stem Cells. 1: 163-173.

SINGH, J.N, JEHAN, Q., SETTY, B.S, KAR, A.B. (1971). Effect of some steroids on spermatogenesis \& fertility of rats. Ind.J. Exp. Biol.9: 132-137.

SINGH, K. (1926). A case of dermoid cyst of the ovary. Ind. Med. Gaz. 61: 71-72.

SIREESHA, G.V., MASON, R.W., HASSANEIN, M., TONACK, S., NAVARRETE SANTOS, A., FISCHER, B. and SESHAGIRI, P.B., (2008). Role of cathepsins in blastocyst hatching in the golden hamster. Mol. Hum. Reprod. 14: 337-346.

SONTAKKE, S.D., PATIL, M.S., UMAPATHY, G., RAO, K.R. and SHIVAJI, S. (2009) Ejaculate characteristics, short-term semen storage and successful artificial insemination following synchronisation of oestrus in the Indian blackbuck antelope (Antilope cervicapra). Reprod. Fertil. Dev. 21: 749-756.

SONTAKKE, S., PATIL, M.S, LAKSHMIKANTAN, U., SHIVAJI, S. (2012). Ultrasonographic characterization of ovarian follicular development in the Indian blackbuck antelope (Antilope cervicapra) Small Rum. Res.105: 222-230.

SONTAKKE, S.D., UMAPATHY, G., SIVARAM, V., KHOLKUTE, S.D. and SHIVAJI, S. (2004). Semen characteristics, cryopreservation, and successful artificial insemination in the Blue rock pigeon (Columba livia). Theriogenol. 62: 139-153.

STEPTOE, P.C. and EDWARDS, R.G. (1978). Birth after the reimplantation of a human embryo. Lancet. 2: 366

SUDHAKAR, D.V.S., NIZAMUDDIN, S., MANISHA, G., DEVI, J.R., GUPTA, N.J. CHAKRAVARTHY, B.N., DEENADAYAL, M., SINGH, L. and THANGARAJ, K (2018). NR5A1 mutations are not associated with male infertility in Indian men. Andrologia 50: 1-8.

SUKESH, B., PUTTABYATAPPA, M., PETER, A.T., MEDHAMURTHY, R. and SESHAGIRI PB. (2017). Assessment of ovarian follicular dynamics and folliculogenesis associated endocrine profiles following gonadotropin stimulation in the bonnet monkey. Gen. Comp. Endocrinol. 253: 25-32.

SURYAVATHI, V., KHATTRI, A., GOPAL, K., RANI, D.S., PANNEERDOSS, S., GUPTA N.J., CHAKRAVARTY, B., DEENADAYAL, M., SINGH, L. and THANGARAJ, K. (2008). Novel variants in UBE2B gene and idiopathic male infertility. J. Androl. 29: 564-571.

TALWAR, G.P., NAZ, R.K., DAS, C. and DAS, R.P. (1979). A practicable immunological approach to block spermatogenesis without loss of androgens. Proc. Nat. Acad. Sci. USA. 76: 5882-5885.

TALWAR, G.P. and SHARMA, S.K. (1975). Systems for evaluation of uterine responses in vitro. Methods Enzymol 39: 101-106.

THOMAS, K.R. and CAPECCHI, M.R. (1987). Site-directed mutagenesis by gene targeting in mouse embryo-derived stem cells. Cell 51: 503-512.

TROUNSON, A. and MOHR, L. (1983). Human pregnancy following cryopreservation thawing and transfer of an eight-cell embryo. Nature. 305: 707-709.

UMAPATHY, G., SONTAKKE, S.D., REDDY, A. and SHIVAJI, S. (2007a). Seasonal variations in semen characteristics, semen cryopreservation, estrus synchronization, and successful artificial insemination in the spotted deer (Axis axis). Theriogenol. 67: 1371-1378.

UMAPATHY, G., SONTAKKE, S.D., SRINIVASU, K., KIRAN, T., KHOLKUTE, S.D. and SHIVAJI, S. (2007b). Estrus behavior and fecal steroid profiles in the Asiatic lion (Panthera leo persica) during natural and gonadotropin-induced estrus. Anim. Reprod. Sci. 101: 313-325.

UMAPATHY, G., KUMAR, V., WASIMUDDIN, K.M. and SHIVAJI, S. (2013). Detection of pregnancy and fertility status in big cats using an enzyme immunoassay based on 5a-pregnan-3a-ol-20-one. Gen. Comp. Endocrinol. 180: 33-38.

VAIDYANATHAN, D. (1950). Umbilical hernia in a buffalo calf. Indian Vet J.27: 53 54. VALE, R.D. and DELL, K. (2009). The biological sciences in India. J. Cell. Biol. 184: 342-353.

VAN BENEDEN, E. and JULIN, Ch. (1880). Observations sur la maturation, la fécondation et la segmentation de l'oeuf chez les Chéiroptères. Arch. Biol. 1: 551-571. 
VERMA, I., RASHIDB, Z., SUJIT, K., SIKDARB, C. and SESHAGIRI, P.B. (2017) .Efficient neural differentiation of mouse pluripotent stem cells in a serumfree medium and development of a novel strategy for enrichment of neural cells. Int. J. Dev. Neur. 61: 112-124.

WAKCHAURE, R., GANGULY, S., PARA, P.A., PRAVEEN, P.K. and QADRI, K.(2015). Relevance and Technological Implications of in vitro Fertilization in Animal Breeding and Reproduction: A Review. Int. J. Emerg. Techn. Adv. Eng. 5: 59-61.

WILLMUT, I., SCHNJEKE, A.E., McWHIR, J., KIND, A.J. and CAMPBELL, K.H.S. (1997). Viable off spring derived from fetal and adult mammalian cells. Nature 385: 810-813.

WPP (2019). World population prospects-2019. Data booklet. United Nations Department of Economic and Social Affairs. (ST/ESA/SER.A/424) (pp. 8,12). 


\section{Further Related Reading, published previously in the Int. J. Dev. Biol.}

A lifetime of deciphering complexities of embryo implantation

Susanne Tranguch and Sudhansu K. Dey.

Int. J. Dev. Biol. (2014) 58: 79-86

https://doi.org/10.1387/ijdb.130332st

Transgenes and their contributions to epigenetic research

Peter Meyer

Int. J. Dev. Biol. (2013) 57: 509-515

https://doi.org/10.1387/ijdb.120254pm

Puzzles of mammalian fertilization - and beyond

J. Michael Bedford

Int. J. Dev. Biol. (2008) 52: 415-426

https://doi.org/10.1387/ijdb.072551jb

A history of mammalian embryological research

Henri Alexandre

Int. J. Dev. Biol. (2001) 45: 457-467

Recent scientific and medical advances in assisted human conception Edwards R.G.

Int. J. Dev Biol. (1997) 41: 255-262
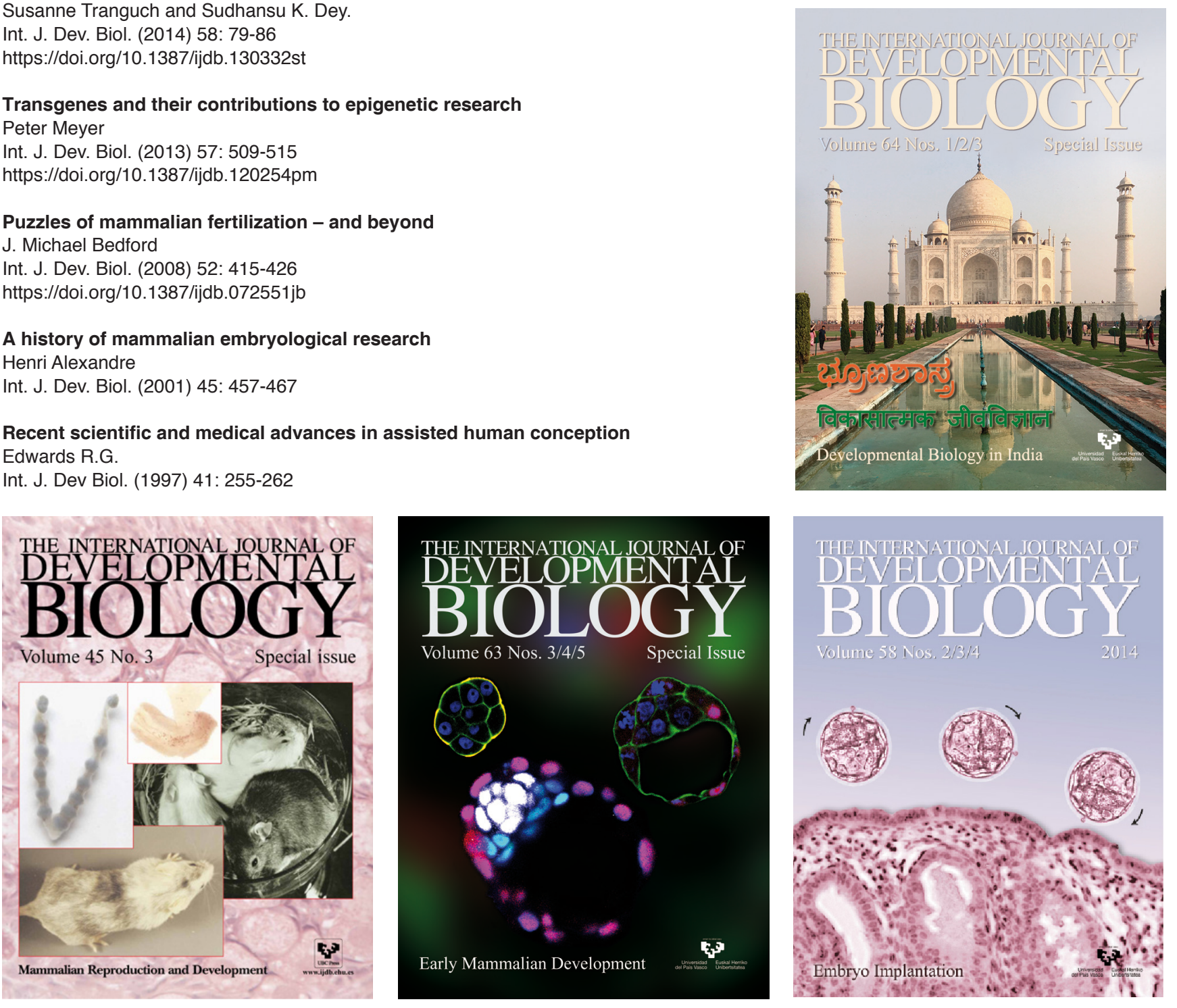